\title{
Isoform-specific regulation of mood behavior and pancreatic $\beta$ cell and cardiovascular function by L-type $\mathrm{Ca}^{2+}$ channels
}

\author{
Martina J. Sinnegger-Brauns,,$^{1,2}$ Alfred Hetzenauer, ${ }^{1}$ Irene G. Huber,,1,2 Erik Renström, ${ }^{3}$ \\ Georg Wietzorrek, ${ }^{1,2}$ Stanislav Berjukov, ${ }^{2}$ Maurizio Cavalli, ${ }^{4}$ Doris Walter, ${ }^{1,2}$ Alexandra Koschak, ${ }^{1}$ \\ Ralph Waldschütz, ${ }^{5}$ Steffen Hering, ${ }^{2}$ Sergio Bova, ${ }^{4}$ Patrik Rorsman, ${ }^{3}$ Olaf Pongs, ${ }^{5}$ \\ Nicolas Singewald, ${ }^{1}$ and Jörg Striessnig ${ }^{1}$
}

\begin{abstract}
${ }^{1}$ Abteilung Pharmakologie und Toxikologie, Institut für Pharmazie, and 2Institut für Biochemische Pharmakologie, Universität Innsbruck, Innsbruck, Austria. ${ }^{3}$ Department of Molecular and Cellular Physiology, Institute of Physiological Sciences, Lund University, Lund, Sweden. ${ }^{4}$ Dipartimento di Farmacologia ed Anestesiologia, Università Degli Studi Di Padova, Padova, Italy. ${ }^{5}$ nstitut für Neurale Signalverarbeitung, Zentrum für Molekulare Neurobiologie, Hamburg, Germany.
\end{abstract}

\begin{abstract}
$\mathrm{Ca}_{\mathrm{v}} 1.2$ and $\mathrm{Ca}_{\mathrm{v}} 1.3 \mathrm{~L}$-type $\mathrm{Ca}^{2+}$ channels (LTCCs) are believed to underlie $\mathrm{Ca}^{2+}$ currents in brain, pancreatic $\beta$ cells, and the cardiovascular system. In the CNS, neuronal LTCCs control excitation-transcription coupling and neuronal plasticity. However, the pharmacotherapeutic implications of CNS LTCC modulation are difficult to study because LTCC modulators cause card iovascular (activators and blockers) and neurotoxic (activators) effects. We selectively eliminated high dihydropyridine (DHP) sensitivity from $\mathrm{Ca}_{\mathrm{v}} 1.2 \alpha 1$ subunits $\left(\mathrm{Ca}_{v}\right.$ 1.2DHP $\left.\mathrm{P}^{-/}\right)$without affecting function and expression. This allowed separation of the DHP effects of $\mathrm{Ca}_{\mathrm{v}} 1.2$ from those of $\mathrm{Ca}_{\mathrm{v}} 1.3$ and other LTCCs. DHP effects on pancreatic $\beta$ cell LTCC currents, insulin secretion, cardiac inotropy, and arterial smooth muscle contractility were lost in $C a_{v} 1.2 D H P^{-/-}$mice, which rules out a direct role of $\mathrm{Ca}_{v} 1.3$ for these physiological processes. Using $\mathrm{Ca}_{v} 1.2 \mathrm{DHP} \mathrm{P}^{-/-}$mice, we established DHPs as mood-modifying agents: LTCC activator-induced neurotoxicity was abolished and disclosed a depressionlike behavioral effect without affecting spontaneous locomotor activity. LTCC activator BayK 8644 (BayK) activated only a specific set of brain areas. In the ventral striatum, BayK-induced release of glutamate and 5-HT, but not dopamine and noradrenaline, was abolished. This animal model provides a useful tool to elucidate whether $\mathrm{Ca}_{\mathrm{v}} 1.3$-selective channel modulation represents a novel pharmacological approach to modify CNS function without major peripheral effects.
\end{abstract}

\section{Introduction}

$\mathrm{Ca}^{2+}$ influx through L-type calcium channels (LTCCs) is an important modulator of neuronal excitability $(1,2,3)$. LTCC activation increases intracellular free $\mathrm{Ca}^{2+}$ concentrations, which may eventually lead to activation of the transcription of genes associated with long-term changes in synaptic plasticity (for review see ref. 3). The coupling of neuronal excitation and transcription may critically depend on the activity of the dihydropyridine-sensitive (DHP-sensitive) LTCCs $\mathrm{Ca}_{\mathrm{v}} 1.2$ and $\mathrm{Ca}_{\mathrm{v}} 1.3$. Thus, these two channels represent very interesting and potentially important therapeutic targets in the CNS. $\mathrm{Ca}_{\mathrm{v}} 1.2$ and $\mathrm{Ca}_{\mathrm{v}} 1.3$ channel blockers, such as nifedipine, ameliorate age-related working memory deficits in rodents (4), have antidepressant-like actions (5), and can affect fear memory (6). On the other hand, LTCC activators, such as BayK 8644 (BayK), stimulate neurotransmitter release in vitro (7), but also induce a severe dystonic neurobehavioral syndrome in rodents, including self-biting (8). $\mathrm{Ca}_{\mathrm{v}} 1.2$ and $\mathrm{Ca}_{\mathrm{v}} 1.3$ have a broad and overlapping

Nonstandard abbreviations used: BayK 8644 (BayK); bed nucleus of the stria terminalis (BNST); dihydropyridine (DHP); inward $\mathrm{Ba}^{2+}$ current $\left(I_{\mathrm{Ba}}\right)$; inward $\mathrm{Ca}^{2}$ current $\left(I_{\mathrm{Ca}}\right)$; L-type $\mathrm{Ca}^{2+}$ channel (LTCC); paraventricular hypothalamic nucleus (PVN); voltage for half-maximal activation $\left(\mathrm{V}_{0.5, \mathrm{act}}\right)$; voltage for half-maximal inactivation $\left(\mathrm{V}_{0.5}\right.$, inact $)$.

Conflict of interest: The authors have declared that no conflict of interest exists.

Citation for this article: J. Clin. Invest. 113:1430-1439 (2004).

doi:10.1172/JCI200420208 expression profile in the mammalian neuronal system, where $\mathrm{Ca}_{\mathrm{v}} 1.2$ appears to be more prominent than $\mathrm{Ca}_{\mathrm{v}} 1.3$ (1).

$\mathrm{Ca}_{v} 1.2$ and $\mathrm{Ca}_{v} 1.3$ have also been detected in many non-neuronal tissues, e.g., insulin-secretory $\beta$ cells $(9,10)$, vascular smooth muscle cells (11), and heart atria (12). Therefore, it remains unclear whether the reported CNS effects of LTCC blockers are due to a direct or indirect action since they also may cause cardiodepression and vasodilation (13). Furthermore, the contribution of $\mathrm{Ca}_{\mathrm{v}} 1.2$ and/or $\mathrm{Ca}_{\mathrm{v}} 1.3$ channels to DHP effects is unknown, because presently available LTCC activators and blockers cannot distinguish between the two channel isoforms.

To allow us to address the relative roles of $\mathrm{Ca}_{v} 1.2$ and $\mathrm{Ca}_{v} 1.3$ in greater detail, we have created a mouse model in which the high DHP sensitivity of $\mathrm{Ca}_{v} 1.2 \alpha 1$ subunits was eliminated by replacement of Thr1066 in helix IIIS5 with a tyrosine residue (14). This essentially eliminates the contribution of this channel type to DHP effects. We used this mouse model to directly determine the contribution of $\mathrm{Ca}_{v} 1.3$ for pancreatic $\beta$ cell Ca ${ }^{2+}$ currents and insulin secretion as well as cardiac and arterial smooth muscle function. We were also able to determine its contribution for high-affinity $(+)-\left[{ }^{3} \mathrm{H}\right]$ isradipine binding in brain and heart, BayKinduced dystonia, BayK effects on regional brain neurotransmitter efflux, and mood-related behavioral DHP effects. Our data indicate that $\mathrm{Ca}_{v} 1.3$-selective activators can cause distinct alterations in CNS function without affecting LTCCs in the cardiovascular system and pancreatic $\beta$ cells. 


\section{Methods}

All animal experiments were approved by the Austrian Bundesministerium für Bildung, Wissenschaft, und Kultur and the local ethical committee at Lund University.

Generation of $\mathrm{Ca}_{v} 1.2 \mathrm{DHP}^{-/-}$mice. Mouse genomic DNA clones (M24166Q3 and B17149Q3) containing IIIS5 (exon 24) encoding regions of the $\mathrm{Ca}_{v} 1.2 \alpha 1$ subunit were isolated from a LAWRIST7 129 mouse strain genomic library (Deutsches Ressourcenzentrum für Genomforschung GmbH, Berlin, Germany). The targeting construct consisted of a 10.3-kb genomic Csp45I-SpeI fragment including the T1066Y mutation (exon 24), a neomycin resistance gene (neo), and the plasmid pBLUESCRIPT (Stratagene, La Jolla, California, USA). T1066Y was generated by overlap-extension PCR (15). The neo gene, flanked by two loxP elements in parallel orientation and driven by the phosphoglycerate kinase promoter, was inserted into the intron sequence 280 -bp upstream of exon 24 by ligating into XhoI and SmaI recognition sites that were generated by overlap extension. The NotI-linearized targeting construct was electroporated into 129 (R1) ES cells, which were subjected to selection by geneticin (G418; Invitrogen Corp., San Diego, California, USA).

Two hundred and ninety-six transfected G418-resistant ES cell colonies were screened for homologous recombination events by Southern blot analysis of BamHI-digested genomic DNA with a 5T external probe $(350 \mathrm{bp})$. The PCR-generated probe detected a $7.5-\mathrm{kb}$ band for the WT and a $9.5-\mathrm{kb}$ band for the mutated allele. The T1066Y mutation was detected by PCR using primers amplifying either the WT (fragment size $841 \mathrm{bp}$ ) or the mutated allele fragment (616 bp).

From 16 positive ES cell clones, two were selected for blastocyst injection to create chimeric mice. Transmission of the mutant $\mathrm{Ca}_{v} 1.2 \alpha 1$ allele from both clones was confirmed by PCR and Southern blot analysis of genomic DNA. The positive F1 progeny were crossed with C57BL/6J mice, and their F2 heterozygous offspring were crossed to generate homozygous knock-ins as well as heterozygous and WT littermates. After crossing of homozygous animals with EIIA-Cre deleter mice to eliminate the neo cassette from the mutated gene, genotyping of the offspring was performed by PCR, yielding fragment sizes of $390 \mathrm{bp}$ and $475 \mathrm{bp}$ for the WT and the mutated allele, respectively. Heterozygous offspring were backcrossed for at least five generations into C57BL/6J mice.

Radioligand binding and membrane preparations were performed as described (16).

Immunohistochemical staining of Fos-positive neurons. To investigate DHP activator effects on CNS function, BayK was used because it is known to activate $\mathrm{Ca}_{v} 1.2$ and $\mathrm{Ca}_{v} 1.3$ LTCCs with similar efficacy (15) and does not block $\mathrm{N}$-type $\mathrm{Ca}^{2+}$ channels like the benzoyl pyrrole FPL 64176 (17).

$\mathrm{Ca}_{v} 1.2 \mathrm{DHP}^{-/-}$mice were injected intraperitoneally with vehicle (10 $\mu \mathrm{l} / \mathrm{g})$ or BayK $(4 \mathrm{mg} / \mathrm{kg})$. A lower dose $(2 \mathrm{mg} / \mathrm{kg})$ was used for WT mice to prevent severe neurotoxicity. Two hours after drug administration, mice were processed for Fos immunostaining according to published procedures (18) using a polyclonal primary antibody (sc-52; Santa Cruz Biotechnology Inc., Santa Cruz, California, USA) and a biotinylated goat anti-rabbit secondary antibody (Vector Laboratories Inc., Burlingame, California, USA). Cells containing a nuclear brownish-black reaction product were considered positive for Fos immunoreactivity and are referred to as Fos-positive cells. The sections were viewed at a magnification of $\times 100$ and the number of Fos-positive cells within a defined area $\left(0.01 \mathrm{~mm}^{2}\right)$ in each region of interest was quantified from one section per mouse. A total of 65 brain regions was systematically analyzed.
Neurotransmitter efflux. Neurotransmitter efflux in the ventral striatum was determined using a micro push-pull superfusion technique. WT or $C a_{v} 1.2 \mathrm{DHP}^{-/-}$mice were anesthetized with urethane $(1.2 \mathrm{~g} / \mathrm{kg}$ ) and mounted in a stereotaxic frame (Trent Wells, South Gate, California, USA), and the push-pull cannula (outer diameter, $0.5 \mathrm{~mm}$; inner diameter, $0.3 \mathrm{~mm}$ ) was inserted unilaterally into the ventral striatum. The coordinates from bregma (19) were as follows (in mm): AP, +1.0; L, 1.2; V, -4.5 . The ventral striatum was superfused with artificial CSF (in $\mathrm{mM}: \mathrm{NaCl}, 140 ; \mathrm{KCl}, 3$; glucose, 3 ; $\mathrm{CaCl}_{2}, 1.25 ; \mathrm{MgCl}_{2}, 1 ; \mathrm{NaH}_{2} \mathrm{PO}_{4}, 1$; and $\mathrm{Na}_{2} \mathrm{HPO}_{4}, 1 ; \mathrm{pH}$ 7.2) using a CMA 100 microinjection pump (CMA Microdialysis AB, Solna, Sweden) at a rate of $14 \mu \mathrm{l} / \mathrm{min}$. Steady-state levels of neurotransmitters were reached 80 minutes after starting the superfusion. Four samples (20-minute sampling time each) were collected thereafter to determine basal extracellular neurotransmitter levels. Subsequently, BayK was applied either locally $(0.1 \mu \mathrm{M}$ added to the CSF) or systemically ( $2 \mathrm{mg} / \mathrm{kg}$ given intraperitoneally), and samples were collected for an additional 60 minutes and 100 minutes, respectively. Samples were immediately stored at $-80^{\circ} \mathrm{C}$ and neurotransmitter concentrations were determined as described (20-22). At the end of the experiment mice were sacrificed with an overdose of sodium pentobarbital, the brain was removed, and the localization of the cannula was verified histologically in 50- $\mu \mathrm{m}$ sections.

Accelerating rotarod test. The accelerating rotarod test was performed as described (23). On days 1-3, mice were given three practice trials separated by 1 minute. On days 4 and 5, mice were given two practice trials, and then a third trial was carried out $20 \mathrm{~min}$ utes after injection of vehicle to habituate the mice to the injection procedures. On day 6, mice were given two practice trials, followed by injection with either vehicle or BayK. Twenty minutes after the injection, the test trial was performed.

Open-field test. The open field consisted of a plastic box $(41 \times 41$ $\times 41 \mathrm{~cm}$ ) equipped with an automated activity monitoring system (TruScan; Coulbourn Instruments, Allentown, Pennsylvania, USA). Illumination at floor level was 500 lux. The test was carried out as described (24). Center entries, center time, center distance, vertical plane entries (rearing), and total distance traveled were recorded.

Forced-swim test. The forced-swim test based on the test established by Porsolt et al. in 1977 was performed as described elsewhere (24). Mice were individually placed in a glass cylinder (diameter, $11.5 \mathrm{~cm}$; height, $24 \mathrm{~cm}$ ) containing $15 \mathrm{~cm}$ fresh tap water maintained at 24 $25^{\circ} \mathrm{C}$. Their activity was videotaped over a period of 6 minutes. The duration of immobility throughout the final 4 minutes of the test was assessed. Four $\mathrm{mg} / \mathrm{kg}$ BayK (or vehicle) was injected intraperitoneally 20 minutes before the test. Twenty-five $\mathrm{mg} / \mathrm{kg}$ nifedipine (or vehicle) was administered 23 hours after a 15 -minute pretest in the absence of drugs and 60 minutes prior to the 6-minute testing period.

Measurement of $\mathrm{I}_{\mathrm{Ba}}$ in neonatal cardiomyocytes. Inward $\mathrm{Ba}^{2+}$ currents $\left(I_{\mathrm{Ba}}\right)$ through voltage-gated $\mathrm{Ca}^{2+}$ channels were recorded at $22-25^{\circ} \mathrm{C}$ using the patch-clamp technique as previously described (25). Patch pipettes (resistance, 1-4 M 2 ) were made from borosilicate glass and filled with pipette solution containing (in $\mathrm{mM}$ ): $\mathrm{CsCl}, 60 ; \mathrm{CsOH}, 60$; aspartate, $60 ; \mathrm{MgCl}_{2}, 2$; HEPES, 10; and EGTA, 10 (adjusted to $\mathrm{pH} 7.25$ with $\mathrm{CsOH}$ ). The bath solution contained (in $\mathrm{mM}$ ): $\mathrm{BaCl}_{2}, 10 ; \mathrm{N}$-methyl-Dglucamine, 190; HEPES, 10; glucose, 20; 4-aminopyridine, 4; tetraethylammonium chloride, 27 ; and $\mathrm{MgCl}_{2}$, 3; buffered to $\mathrm{pH} 7.4$ with methanesulfonic acid. All data were digitized and filtered at $2 \mathrm{kHz}$ with a four-pole Bessel filter. Leak currents were subtracted digitally (using average values of scaled leak- 


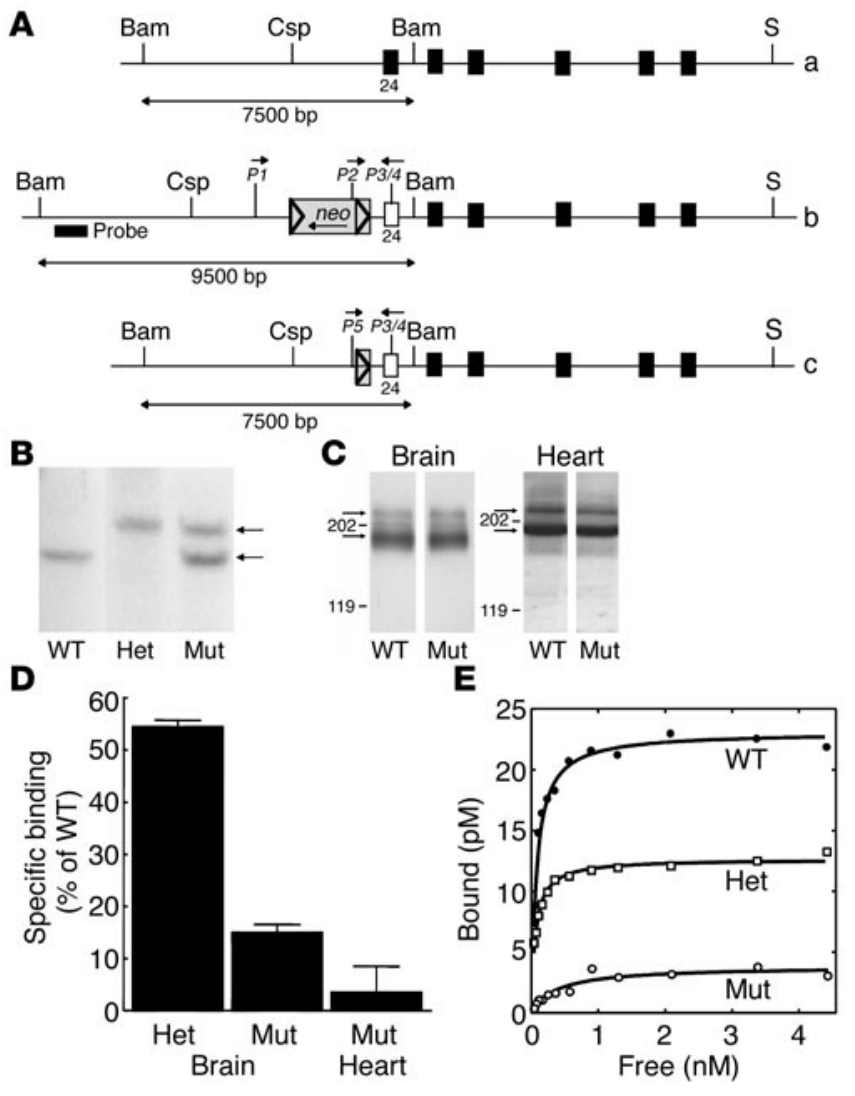

age currents elicited by a $10-\mathrm{mV}$ hyperpolarizing pulse) or electronically by means of an analogue circuit.

Pancreatic islet experiments. Pancreatic islets were isolated and insulin release was measured in static batch incubations by RIA, as described (26). Voltage-gated $\mathrm{Ca}^{2+}$ currents were recorded using the perforatedpatch whole-cell approach. To block a prominent outward delayed rectifying $\mathrm{K}^{+}$current and to resolve the inward $\mathrm{Ca}^{2+}$ current component, the extracellular buffer was supplemented with $20 \mathrm{mM}$ tetraethylammonium chloride (TEA-Cl), and the pipette solution was made using $\mathrm{Cs}^{+}$. The extracellular $\mathrm{Ca}^{2+}$ concentration was $2.6 \mathrm{mM}$. Effects of isradipine and BayK were determined in the steady state.

DHP effects on contractility of isolated cardiac muscle and mouse aortic rings. Isometric contractions (resting tension of $0.5 \mathrm{~g}$ ) of mouse aortic rings were recorded as described (27). After equilibration (>60 $\mathrm{min}$ ) they were repeatedly stimulated with phenylephrine $(1 \mu \mathrm{M})$ until reproducible contractile responses were obtained. The effect of isradipine was tested on rings that were exposed to $90 \mathrm{mM} \mathrm{KCl}$ and allowed to contract until the responses reached a plateau. Parallel experiments were done to exclude an effect of the solvent (DMSO). BayK effects were measured on rings partially contracted with $15 \mathrm{mM} \mathrm{KCl}$.

Langendorff isolated perfused hearts were mounted as described (28) with minor modifications. Briefly, the hearts from previously heparinized mice were quickly explanted and perfused through the aorta at constant flow $(2 \mathrm{ml} / \mathrm{min})$, and the atria were removed. The perfusion solution (containing in $\mathrm{mM}: \mathrm{NaCl}, 118 ; \mathrm{KCl}, 4.7 ; \mathrm{CaCl}_{2}, 2.5$; $\mathrm{MgSO}_{4}, 1.2 ; \mathrm{NaCO}_{3}, 25 ; \mathrm{KH}_{2} \mathrm{PO}_{4}, 1.2 ;$ glucose, $11.1 ;$ and Na pyruvate, 2) was bubbled with a $95 \% \mathrm{O}_{2}, 5 \% \mathrm{CO}_{2}$ gas mixture $(\mathrm{pH} 7.4 \pm 0.01)$ at $37^{\circ} \mathrm{C}$. After a stabilization period of 30 minutes, the hearts were electrically stimulated at a frequency of $5.5 \mathrm{~Hz}$ by placing a platinum electrode on the upper part of the right ventricle. Contractility was

\section{Figure 1}

Construction of $\mathrm{Ca}_{v} 1.2 \mathrm{DHP} \mathrm{P}^{-/-}$mice. (A) Map of WT (a) and mutant (b) $\mathrm{Ca}_{v} 1.2 \alpha 1$ alleles. neo, neomycin resistance gene flanked by loxP elements (triangles); 24, exon containing T1066Y mutation in IIIS5. Primers P1 to P5 were used to detect T1066Y. (c) Mutated allele after neo excision. Bam, BamHI; Csp, Csp45I; S, Spel. (B) Southern blot analysis of genomic DNA from WT, heterozygous (Het), and homozygous $\left(\mathrm{Ca}_{v} 1.2 \mathrm{DHP}^{-l_{-}}\right)$mutants (Mut) after BamHI digestion using the probe indicated in A. Arrows indicate bands from WT (7.5 kb) and mutant alleles (9.5 kb). (C) Immunoblots (see Methods): Arrows indicate migration of short (160-190 kDa) and long (220 kDa) forms of specific $\mathrm{Ca}_{\mathrm{v}} 1.2 \alpha 1$ immunoreactivity. Migration of molecular mass standards $(\mathrm{kDa})$ is indicated. One representative experiment of three is shown. (D) Equilibrium $(+)-\left[{ }^{3} \mathrm{H}\right]$ isradipine binding $(0.9-1.4 \mathrm{nM})$ to heart or brain membranes (10-20 $\mu \mathrm{g} / \mathrm{ml}$ protein). Specific binding in heterozygous and homozygous brain is expressed as percentages of WT binding. Nonspecific binding was defined in the presence of $1 \mu \mathrm{M}$ isradipine. $(\mathbf{E})(+)-\left[{ }^{3} \mathrm{H}\right]$ isradipine saturation binding analysis in brain membranes of WT (closed circles), heterozygous (open squares), and homozygous mutant (open circles) mice. One representative experiment of five is shown. WT, $K_{\mathrm{D}}=0.076 \mathrm{nM}$, maximal binding capacity $\left(B_{\max }\right)=23.1 \mathrm{pM}(462 \mathrm{fmol} / \mathrm{mg})$; heterozygous mutants: $K_{\mathrm{D}}=0.067$ $\mathrm{nM}, B_{\max }=12.8 \mathrm{pM}(255 \mathrm{fmol} / \mathrm{mg})$; homozygous mutants: $K_{\mathrm{D}}=0.347$ $\mathrm{nM}, B_{\max }=3.81 \mathrm{pM}(76 \mathrm{fmol} / \mathrm{mg})$.

measured by placing in the left ventricle a steel cannula connected to a pressure transducer (Ugo Basile, Comerio, Italy). The hearts were allowed to stabilize for at least 60 minutes before drug exposure.

Telemetric recordings. Telemetric recordings were carried out as described previously (29). Control ECGs were recorded continuously (sampling rate, $500 \mathrm{~Hz}$ ) from freely moving mice at least 2 days after transmitter implantation. Mice were then injected with $1 \mathrm{mg} /$ $\mathrm{kg}$ of atropine followed by $20 \mathrm{mg} / \mathrm{kg}$ of propranolol to eliminate sympathetic and parasympathetic control of heart rate. Increasing concentrations of DHPs were then injected and heart rate was analyzed during 60-minute periods 20 minutes after drug application.

Immunoblotting. Immunoblots of brain and heart microsomal membranes were carried out as described (29). Thirty micrograms of membrane protein separated on 5\% SDS-polyacrylamide gels and immunoblots probed with affinity-purified rabbit antibody anti-Ca $\mathrm{Ca}_{v} 1.2 \alpha 1_{818-835}$ (29). Specific staining was determined by preincubating antibodies with $0.25 \mu \mathrm{M}$ antigenic peptide. This completely eliminated staining of the immunoreactive bands illustrated in Figure 1C.

Drug dilutions. For binding studies, unlabeled drugs were serially diluted in DMSO. For in vivo tests, BayK $(10 \mu \mathrm{l} / \mathrm{g})$ was freshly dissolved in a solution consisting of $0.8 \%$ ( $\mathrm{vol} / \mathrm{vol}$ ) ethanol and $0.8-1 \%$ (vol/vol) Tween 80 in $0.9 \%$ (wt/vol) NaCl. Nifedipine was suspended in $0.9 \%$ (wt/vol) $\mathrm{NaCl}$ containing $1 \%$ (vol/vol) Tween 80. Desipramine was dissolved in purified water $(10 \mathrm{mg} / 10 \mathrm{ml})$.

Statistics. Data are given as mean \pm SEM for the indicated number of experiments. Tests used for calculation of statistical significance are given in the corresponding sections.

\section{Results}

High DHP sensitivity of $\mathrm{Ca}_{v} 1.2$ LTCCs is absent in $\mathrm{Ca}_{v} 1.2 \mathrm{DHP}^{-/-}$mice. The gene-targeting strategy is illustrated in Figure 1A. Successful gene targeting and the generation of homozygous mutants were confirmed by Southern blot analysis of genomic DNA (Figure 1B). In immunoblots, no effects of the mutation on $\mathrm{Ca}_{\mathrm{v}} 1.2 \alpha 1$ expression density were detected in brain and heart membranes (Figure 1C) and after heterologous expression in tsA-201 cells ( $n=2$, not shown). 
Figure 2

Biophysical properties of $\mathrm{Ca}_{\mathrm{v}} 1.2$ currents in $\mathrm{Ca}_{v} 1.2 \mathrm{DHP}^{-/-}$cardiomyocytes. (A and $\mathbf{B}$ ) $I_{\mathrm{Ba}}$ through LTCCs was recorded from cardiomyocytes isolated from neonatal WT or homozygous mutant mice. Currents recorded with no treatment $(\mathrm{CO})$ or 3 minutes after perfusion with $1 \mu \mathrm{M}$ isradipine (ISR 1) or 0.1 $\mu \mathrm{M}$ BayK (BayK 0.1) and $1 \mu \mathrm{M}$ BayK (BayK 1). Holding potential, $-80 \mathrm{mV}$; test potential, +10 $\mathrm{mV}$. One of more than three experiments yielding similar results is shown. (C) Concentrationdependent isradipine inhibition. Each curve was constructed from experiments $(n=5)$ as described in A. (D) Time constants $(\tau)$ for current inactivation during 300-ms depolarizations from $-80 \mathrm{mV}$ to different test potentials were obtained by fitting the inactivation data to a monoexponential function. No statistically significant difference was found between myocytes from WT and mutant mice.
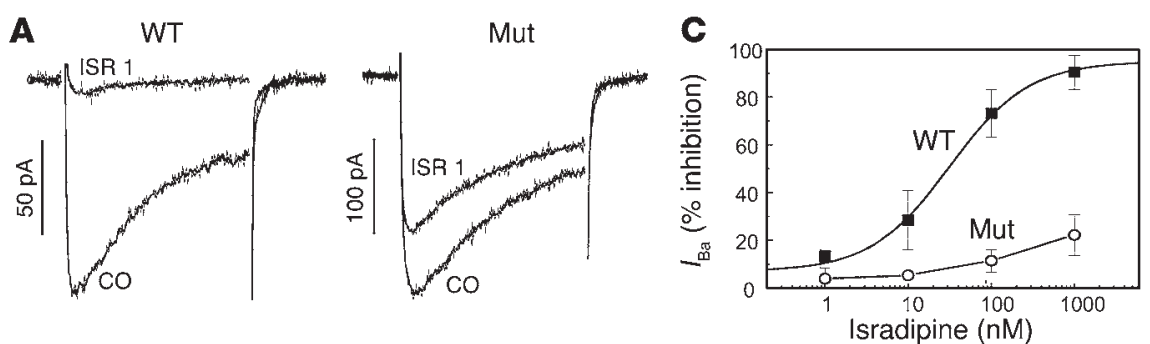

$\mathbf{B}$
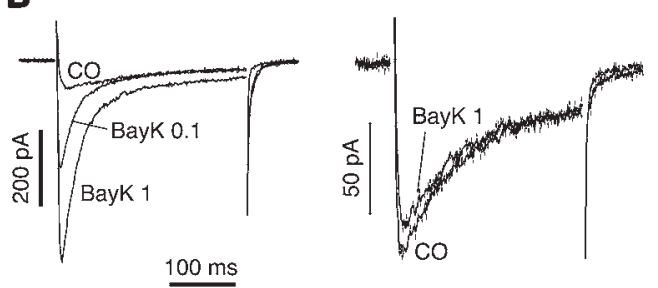

D

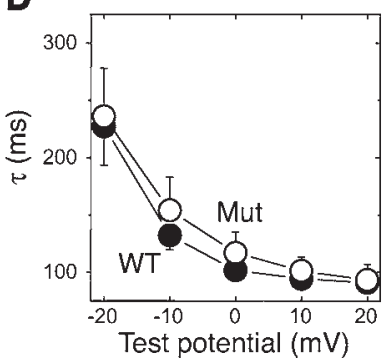

No detectable change of the expression pattern of mRNA of $\mathrm{Ca}_{v} 1.2$ or other $\mathrm{Ca}^{2+}$ channel $\alpha 1$ subunits was found in the mutant mouse brains ( $n=3$, not shown). Selective labeling of LTCCs with 0.9-1.4 $\mathrm{nM}(+)-\left[{ }^{3} \mathrm{H}\right]$ isradipine revealed a decrease of specific DHP binding to $55 \% \pm 2 \%$ and $15 \% \pm 2 \%(n=8)$ of WT values in brain membranes of heterozygous and homozygous mutants, respectively (Figure 1D). No significant binding remained in the heart membranes of homozygous mutants ( $4 \% \pm 5 \% ; n=6$ ) (Figure 1D). The reduced isradipine binding in brain could be attributed to a lower maximal binding capacity, which was $55 \%$ of WT values $(426 \pm 21 \mathrm{fmol} / \mathrm{mg}$ of protein) in heterozygous $(237 \pm 17 \mathrm{fmol} / \mathrm{mg})$ and $20 \%$ in homozygous mutants $(88 \pm 9 \mathrm{fmol} / \mathrm{mg} ; n=7)$. Residual binding was of high affinity $\left(K_{\mathrm{D}}\right.$ in pM: WT, $78 \pm 17$; heterozygous, $96 \pm 27$; homozygous, $175 \pm 42$; $n=7$ ) and stimulated by (+)-tetrandrine (to $318 \% \pm 19 \%$ of control binding in the absence of drug; $\left.\mathrm{EC}_{50}=0.57 \pm 0.46 \mu \mathrm{M} ; n=4\right)$. Therefore $(+)$ $\left[{ }^{3} \mathrm{H}\right]$ isradipine binding in $\mathrm{Ca}_{v} 1.2 \mathrm{DHP} \mathrm{P}^{-/-}$brains exhibits all pharmacological characteristics of LTCCs. As $20-25 \%$ of $(+)-\left[{ }^{3} \mathrm{H}\right]$ isradipine binding is associated with $\mathrm{Ca}_{v} 1.3$ in $\mathrm{Ca}_{v} 1.3$-deficient mice (30), and no other neuronal LTCC $\alpha 1$ subunits are known to exist in the brain, residual binding must be associated with $\mathrm{Ca}_{v} 1.3$ LTCCs.

Next we confirmed that the mutation eliminates high DHP sensitivity of $\mathrm{Ca}_{v} 1.2$ without changing its functional properties. We therefore recorded whole-cell currents $\left(I_{\mathrm{Ba}}\right)$ from neonatal ventricular cardiomyocytes, which are believed to exclusively express $\mathrm{Ca}_{\mathrm{v}} 1.2$ (12). The biophysical characteristics of $I_{\mathrm{Ba}}$ measured from cultured neonatal $\mathrm{Ca}_{v} 1.2 \mathrm{DHP}^{-/-}$cardiomyocytes were indistinguishable from WT cardiomyocytes. Inactivation during depolarizations (Figure $2, \mathrm{~A}, \mathrm{~B}$, and D), steady-state activation (voltage for half-maximal activation $\left[\mathrm{V}_{0.5}\right.$, act $]$ : WT, $16 \pm 1 \mathrm{mV} ; n=11$; mutant, $15 \pm 2 \mathrm{mV} ; n=14$ ), and steady-state inactivation (voltage for half-maximal inactivation $\left[\mathrm{V}_{0.5 \text {, inact }}\right]$ : WT, $44 \pm 2 \mathrm{mV} ; n=6$; mutant, $41 \pm 2 \mathrm{mM} ; n=4$ ) were not measurably affected by the mutation. Despite the absence of alterations in channel gating, the homozygous mutants showed a dramatic decrease in DHP sensitivity. Whereas WT channels were completely blocked by isradipine with an $\mathrm{IC}_{50}$ of $31 \pm 4 \mathrm{nM}(n=5)$, only $21 \% \pm 4 \%(n=5)$ of $I_{\mathrm{Ba}}$ was blocked by $1 \mu \mathrm{M}$ of the drug in mutants, indicating a sensitivity decrease of more than a hundredfold (extrapolated $\mathrm{IC}_{50}>3 \mu \mathrm{M}$ ). The concentration-dependent activation of $I_{\mathrm{Ba}}$ by the $\mathrm{Ca}^{2+}$ channel activator BayK (Figure 2; increase to $581 \% \pm 13 \%$ of control $I_{\mathrm{Ba}}$ at $\left.1 \mu \mathrm{M} ; n=4\right)$ was completely absent in cardiomyocytes isolated from mutant mice ( $87 \% \pm 3 \%$ of control; $n=3)$. Given the known BayK sensitivity of all known L-type channels $(12 ; 31)$, we conclude from these data that $\mathrm{Ca}_{v} 1.2 \mathrm{DHP} \mathrm{P}^{-/}$mice should allow discrimination of DHP effects on $\mathrm{Ca}_{v} 1.2$ from other LTCCs in vitro and in vivo. We previously found that isradipine blocks recombinant $\mathrm{Ca}_{\mathrm{v}} 1.3$ channels under similar experimental conditions with an $\mathrm{IC}_{50}$ of $300 \mathrm{nM}$ (15). Therefore the in vivo mutation of Thr1066 converted the about tenfold selectivity of isradipine for $\mathrm{Ca}_{v} 1.2(15)$ to an at least tenfold selectivity for $\mathrm{Ca}_{\mathrm{v}} 1.3$, making this DHP a selective $\mathrm{Ca}_{\mathrm{v}} 1.3$ channel blocker in $\mathrm{Ca}_{v} 1.2 \mathrm{DHP} \mathrm{P}^{-/-}$mice.

Lack of $C a_{v} 1.3$ LTCC contribution to cardiac and arterial smooth muscle contraction. As illustrated in Figure 3, smooth muscle relaxant and negative inotropic actions of isradipine were completely absent in $C a_{v} 1.2 \mathrm{DHP}^{-/-}$mice. As expected, the mutation did not affect verapamil sensitivity. Verapamil at a concentration of $1 \mu \mathrm{M}$ caused an almost complete block of cardiac contraction in WT (not shown) and mutant mouse hearts $(11.9 \% \pm 3.5 \%$ of control, $n=4)$. Surprisingly, we also found that isradipine was even able to slightly enhance cardiac inotropy. This revealed an unexpected pharmacological action of isradipine, which is normally masked by the loss of contractility through $\mathrm{Ca}_{v} 1.2$ LTCC block. We telemetrically recorded DHP effects on intrinsic sinoatrial node activity in mice pretreated with atropine and propranolol to eliminate autonomic control. BayK caused only a slight increase in heart rate in WT mice that was absent in mutants (Figure 3E). The bradycardiac effect of isradipine in WT mice (Figure $3 \mathrm{E})$ was not affected by the mutation. These data significantly extend our previous in vitro data demonstrating the importance of $\mathrm{Ca}_{v} 1.3$ for sinoatrial node function (29). We show that cardiac and smooth muscle inotropy are controlled by $\mathrm{Ca}_{\mathrm{v}} 1.2$ but not $\mathrm{Ca}_{\mathrm{v}} 1.3$ activity, despite $\mathrm{Ca}_{v} 1.3$ mRNA expression in aortic smooth muscle (11).

$C a_{v} 1.3$ activity does not contribute to pancreatic $\beta$ cell $\mathrm{Ca}^{2+}$ currents and insulin secretion. Our animal model also allowed us to address the still-controversial issue concerning the contribution of $\mathrm{Ca}_{\mathrm{v}} 1.3$ to pancreatic $\beta$ cell $\mathrm{Ca}^{2+}$ currents and insulin secretion. Three different mouse models as well as biochemical data have provided evidence both for a role of $\mathrm{Ca}_{v} 1.3$ in $\beta$ cells $(9,10)$ and against it $(26$, 32 ). In our mice, DHP-sensitive $\mathrm{Ca}^{2+}$ current components in $\beta$ cells 
A

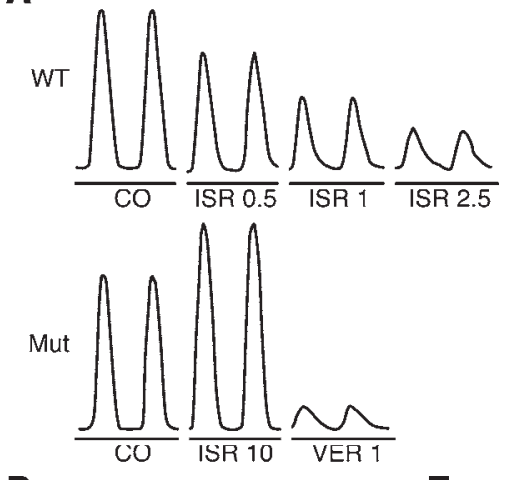

B

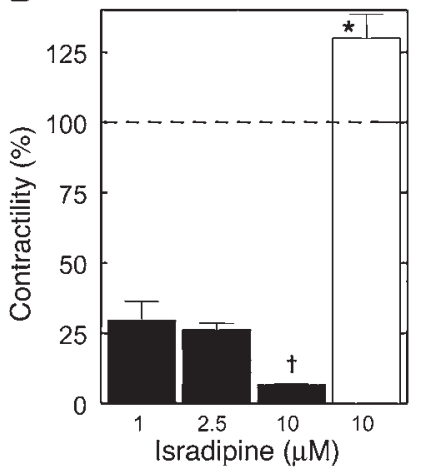

C

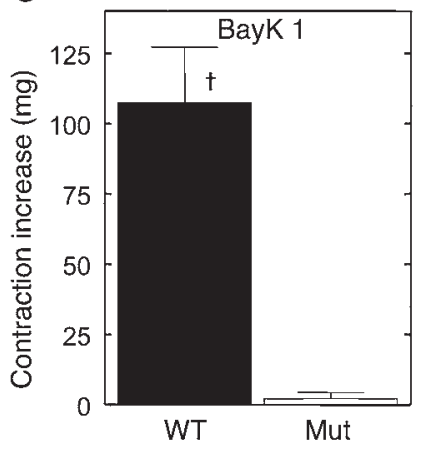

D

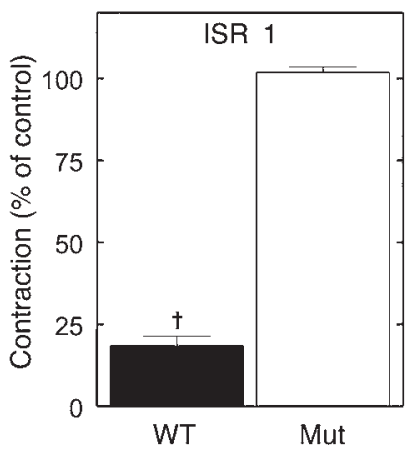

E

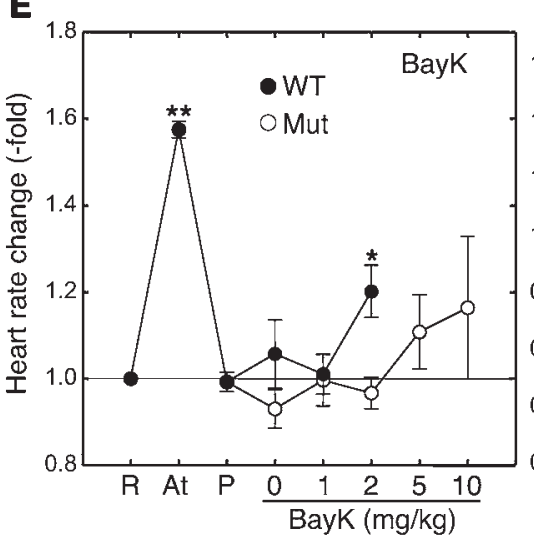

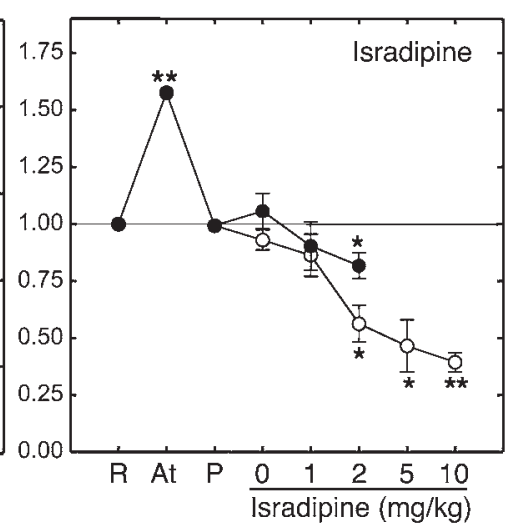

Figure 3

DHP effects on heart and smooth muscle. (A) Representative experiment illustrating drug effects on cardiac ventricle contractility in Langendorff hearts from WT or homozygous mutant $\mathrm{Ca}_{v} 1.2 \mathrm{DHP}^{-/-}$mice. Electrically stimulated hearts were superfused with isradipine (ISR) at concentrations of $0.5 \mu \mathrm{M}, 1 \mu \mathrm{M}, 2.5 \mu \mathrm{M}$, and $10 \mu \mathrm{M}$ or with $1 \mu \mathrm{M}$ verapamil (VER) (see Results). (B) Percent inhibition of contractility in six WT (black bars) and seven mutant (white bar) mice. Statistical significance: ${ }^{\dagger} P<0.001$ (compared with Mut; one-way ANOVA followed by the Bonferroni multiple-comparison test); ${ }^{*} P<0.05$ (compared with contractility in the absence of isradipine, $100 \%$; one-sample Student $t$ test). Data from $1 \mu \mathrm{M}$ and $2.5 \mu \mathrm{M}$ isradipine (mean \pm range of $n=2$ ) were not included in the significance analysis. (C) BayK-induced $(1 \mu \mathrm{M})$ contraction of aortic smooth muscle rings from WT $(n=10)$ or mutant mice $(n=10)$. ${ }^{\dagger} P<0.001\left(\mathrm{Ca}_{v} 1.2 D H P^{-/-}\right.$vs. WT; unpaired Student's $t$ test). (D) Effect of isradipine $(1 \mu \mathrm{M})$ on aortic smooth muscle rings isolated from WT $(n=10)$ or mutant mice $(n=10)$ precontracted with $90 \mathrm{mM} \mathrm{KCl}$. ${ }^{\dagger} P<0.001\left(\mathrm{Ca}_{v} 1.2 D H P^{-1-}\right.$ vs. WT; unpaired Student's $t$ test). (E) Telemetric recordings (see Methods). Effects of increasing doses of BayK (left) and isradipine (right) on sinoatrial activity in vivo. R, resting, no drug. At, injection with atropine $(1 \mathrm{mg} / \mathrm{kg})$; P, injection with atropine followed by propranolol $(20 \mathrm{mg} / \mathrm{kg})$ before DHP application. Data presented as mean SEM of 4-52 experiments. ${ }^{\star} P<0.05$; ${ }^{\star \star} P<0.01$ for heart rate inhibition in the presence of drug (one-sample Student's $t$ test).

or insulin secretion would indicate a contribution of $\mathrm{Ca}_{v} 1.3$. Figure 4, A and B, illustrates that $2 \mu \mathrm{M}$ isradipine inhibited $46 \% \pm 11 \%$ $(n=4 ; P<0.05)$ of the total $I_{\mathrm{Ca}}$ in $\beta$ cells from WT mice, in good accordance with previous findings $(32,33)$. As expected, $\mathrm{L}$-type $\mathrm{Ca}^{2+}$ inward current $\left(I_{\mathrm{Ca}}\right)$ was stimulated about twofold by $2 \mu \mathrm{M}$ BayK (Figure 4, A and B) over a broad voltage range. In contrast, neither BayK nor isradipine significantly modulated $I_{C a}$ in $\mathrm{Ca}_{v} 1.2 \mathrm{DHP} \mathrm{P}^{-/-}$ mice $(n=5)$. This suggests that $\mathrm{Ca}_{\mathrm{v}} 1.3$ does not contribute to $I_{\mathrm{Ca}}$ to a significant extent. Furthermore, glucose-dependent insulin secretion from isolated islets (Figure 4C) was also not DHP sensitive in $\mathrm{Ca}_{v} 1.2 \mathrm{DHP}^{-/-}$mice. This suggests that effects of $\mathrm{Ca}_{\mathrm{v}} 1.3$-selective modulators on CNS function are unlikely to originate from insulin-mediated metabolic or cardiovascular disturbances.

BayK-induced neurotoxicity is $\mathrm{Ca}_{v} 1.2$ dependent. In WT mice, injection of low doses ( $2 \mathrm{mg} / \mathrm{kg}$ ) of BayK (but not of vehicle) produced mild to moderate motor disability (motor impairment score 2-3; see ref. 8), with limited ambulation, hypokinesia, and frequent abnormal postures $(n=5)$ (Figure 5). Higher doses $(4-6 \mathrm{mg} / \mathrm{kg}, n=3)$ led to severe behavioral impairment (score > 3), including self-biting (not shown)
(34). In contrast, no changes in motor function or abnormal behaviors were noticed in homozygous mutants given $2 \mathrm{mg} / \mathrm{kg}$ BayK subcutaneously $(n=5)$ (Figure 5). BayK at $4 \mathrm{mg} / \mathrm{kg}$ did not affect motor function in the rotarod treadmill test (time spent on rotarod: vehicle treatment, $263.8 \pm 14.1 \mathrm{~s}, n=9$; BayK treatment, $254.3 \pm 14.7 ; n=10$; $P=0.671$ by Mann-Whitney $U$ test). To test whether $C a_{v} 1.2 \mathrm{DHP} \mathrm{H}^{-/}$ mice tolerate even higher doses of BayK, mutants were injected with up to $10 \mathrm{mg} / \mathrm{kg}$ of BayK. Mice receiving 5 or $10 \mathrm{mg} / \mathrm{kg}$ subcutaneously showed no motor symptoms or abnormal behavior within 60 minutes $(n>8)$. This demonstrates that $\mathrm{Ca}_{\mathrm{v}} 1.2$ activation is required for BayK-induced neurotoxicity. The absence of toxic symptoms in $\mathrm{Ca}_{v} 1.2 \mathrm{DHP}^{-/-}$mice allowed us to further investigate the consequences of selective $\mathrm{Ca}_{\mathrm{v}} 1.3$ activation on brain function.

$C a_{v} 1.3$ selectively contributes to BayK-induced Fos expression. $\mathrm{Ca}_{v} 1.2$ and $\mathrm{Ca}_{\mathrm{v}} 1.3$ LTCCs have a broad and overlapping expression pattern in the brain (1). The selective $\mathrm{Ca}_{v} 1.3$ activation in $\mathrm{Ca}_{v} 1.2 \mathrm{DHP} \mathrm{P}^{--}$mice by BayK allowed us to identify neurons activated after selective $\mathrm{Ca}_{\mathrm{v}} 1.3$ stimulation in vivo. Fos expression was used as a marker of neuronal activation (see ref. 18 and references therein). 
A

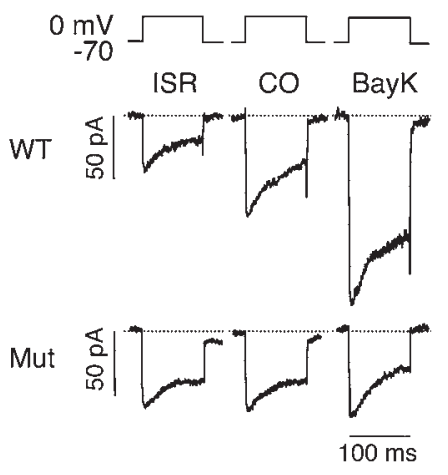

B

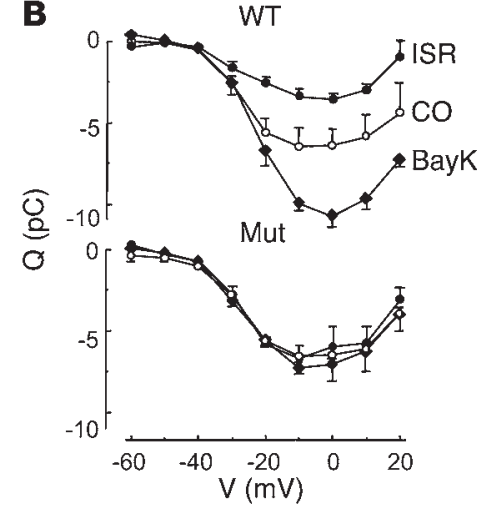

C

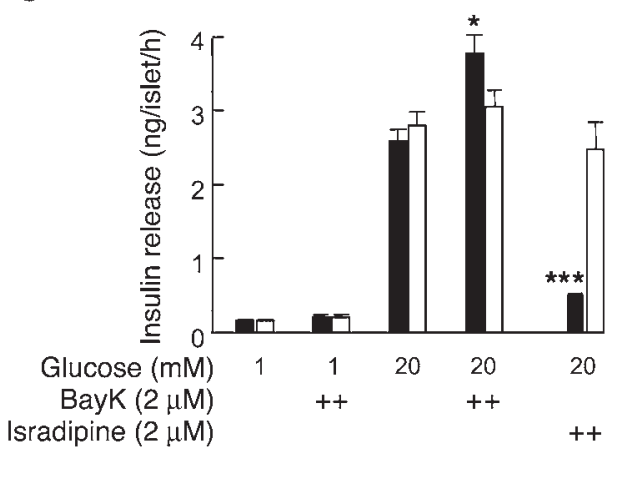

\section{Figure 4}

DHP sensitivity of L-type $I_{\mathrm{Ca}}$ and insulin secretion in isolated pancreatic $\beta$ cells. (A) Whole-cell $I_{\mathrm{Ca}, \mathrm{L}}$ during $100-\mathrm{ms}$ depolarizations from $-70 \mathrm{mV}$ to $0 \mathrm{mV}$ in single pancreatic $\beta$ cells isolated from WT and $C a_{v} 1.2 D H P^{-1-}$ mice. The L-type channel activator BayK $(2 \mu \mathrm{M})$ or the L-type channel inhibitor isradipine $(2 \mu \mathrm{M})$ were added as indicated. (B) Charge-voltage $(Q-V)$ relations recorded in $\beta$ cells (100-ms depolarizations to voltages between $-60 \mathrm{mV}$ and $+20 \mathrm{mV}$ ) from WT and $\mathrm{Ca}_{\mathrm{v}} 1.2 \mathrm{DHP}^{-/-}$mice in the absence (open circles) or presence of BayK (filled diamonds) or isradipine (filled circles). Data represent mean \pm SEM $(n=4-5)$. In WT $\beta$ cells the effects of isradipine and BayK were significant $(P<0.05$; Student $t$ test) at depolarizations beyond $-30 \mathrm{mV}$ and $-10 \mathrm{mV}$, respectively. (C) Insulin secretion measured in isolated islets from control (black bars) and $\mathrm{Ca}_{v} 1.2 \mathrm{DHP} \mathrm{P}^{-/-}$(white bars) mice in the absence and presence of glucose and DHPs as indicated. Data are mean $\pm \mathrm{SEM}(n=6)$. ${ }^{* \star *} P<0.001$ (Student $t$ test) for isradipine inhibition; ${ }^{*} P<0.05$ for BayK stimulation (WT vs. $C a_{v} 1.2 D H P^{-1-}$ ).

Vehicle injection elicited only low levels of Fos-positive cells, which were similar in number in WT (not shown) and mutant mice (Figure 6A). BayK (2 mg/kg) evoked widespread Fos expression in brains of WT mice in most of the 65 brain areas investigated $(n=3)$. Induction was absent in only a few brain areas such as the ventral posteromedial thalamic nucleus or the mammillary nucleus $(n=3$; not shown). The most prominent increase in Fos expression was observed in the infralimbic cortex (BayK, $32.7 \pm 1.8$ cells/0.01 $\mathrm{mm}^{2}$; vehicle, $8.8 \pm 1.7$ cells $\left./ 0.01 \mathrm{~mm}^{2} ; P<0.02\right)$, the pyramidal cell layer of the hippocampus (BayK, $33.3 \pm 1.8$ cells $/ 0.01 \mathrm{~mm}^{2}$; vehicle, $9.4 \pm 1.3$ cells $/ 0.01 \mathrm{~mm}^{2} ; P<0.02$ ), the retrosplenial granular cortex (BayK, $49.0 \pm 1.5$ cells $/ 0.01 \mathrm{~mm}^{2}$; vehicle, $15.0 \pm 1.8$ cells $/ 0.01 \mathrm{~mm}^{2}$; $P<0.02$ ), and the locus coeruleus (BayK, $40.3 \pm 2.4$ cells $/ 0.01 \mathrm{~mm}^{2}$; vehicle, $3.6 \pm 0.7$ cells $\left./ 0.01 \mathrm{~mm}^{2} ; P<0.01\right)$. Figure 6 A illustrates BayK-induced Fos expression in the cingulate cortex and dorsal striatum in WT animals. In the mutant mice $(n=8)$, BayK-induced Fos expression was greatly attenuated in most brain regions compared with WT mice. As illustrated in Figure 6A, BayK failed to enhance the number of Fos-positive cells in the cingulate cortex (BayK, $22.5 \pm 1.3$ cells $/ 0.01 \mathrm{~mm}^{2}$; vehicle, $21.0 \pm 1.5$ cells $/ 0.01 \mathrm{~mm}^{2}$; $P=0.45)$ and dorsal striatum. In striatal sections from mutants, no expression above the levels of vehicle controls was found in the caudate putamen (BayK, $8.6 \pm 0.7$ cells $/ 0.01 \mathrm{~mm}^{2}$; vehicle, $7.9 \pm 1.1$ cells $\left./ 0.01 \mathrm{~mm}^{2} ; P=0.8\right)$. However, significant BayK-induced Fos expression in $\mathrm{Ca}_{v} 1.2 \mathrm{DHP}^{-/-}$mice was detectable in a limited subset of brain regions. Figure 6 illustrates Fos induction in mutants by BayK in the nucleus accumbens (BayK, $19.0 \pm 1.4$ cells $/ 0.01 \mathrm{~mm}^{2}$; vehicle, $12.9 \pm 2.9$ cells $/ 0.01 \mathrm{~mm}^{2} ; P<0.01$; Figure $\left.6 \mathrm{~B}\right)$ and the bed nucleus of the stria terminalis (BNST): BayK, $27.5 \pm 1.8$; vehicle, $6.3 \pm 0.9 ; P<0.001$; Figure $6 \mathrm{C}$ ). High levels of BayK-induced Fos expression were also observed in the paraventricular hypothalamic nucleus $(\mathrm{PVN})\left(\mathrm{BayK}, 45.6 \pm 2.6\right.$ cells $/ 0.01 \mathrm{~mm}^{2}$; vehicle, $8.7 \pm 2.1$ cells $/ 0.01 \mathrm{~mm}^{2}$ ) and the central amygdaloid nucleus (BayK, $22.6 \pm 1.8$ cells $/ 0.01 \mathrm{~mm}^{2}$; vehicle, $6.5 \pm 0.9$ cells $/ 0.01$ $\mathrm{mm}^{2}$ ). These experiments revealed that most of the BayK-induced neuronal activation in mouse brain in vivo is mediated by $\mathrm{Ca}_{\mathrm{v}} 1.2$ but that selective $\mathrm{Ca}_{v} 1.3$ activation still stimulates Fos expression in a distinct set of brain areas without causing obvious toxic reactions.

Based on pharmacokinetic data of various DHPs in mice, micromolar BayK concentrations must be achieved in brain after intraperitoneal application of $4 \mathrm{mg} / \mathrm{kg}$ (see legend to Figure 6D). At these concentrations BayK stimulates the activity of $\mathrm{Ca}_{v} 1.3$ but not mutant $\mathrm{Ca}_{\mathrm{v}}$ 1.2 LTCCs (Figure 6D).

$C a_{v} 1.3$ activation contributes to BayK-stimulated neurotransmitter efflux in the ventral striatum. We next determined to what extent $\mathrm{Ca}_{\mathrm{v}} 1.3$ activation alone contributes to the known BayK-induced neurotransmitter overflow in the CNS in vivo. The ventral striatum was selected to measure neurotransmitter efflux. In this region, efflux of various monoamines and amino acids has been successfully determined (35). LTCC isoforms are also

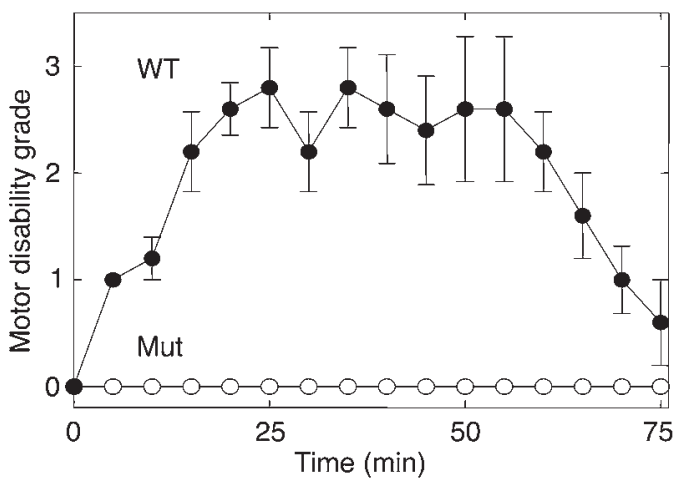

Figure 5

BayK-induced changes in motor disability grade in WT and $\mathrm{Ca}_{v}$ 1.2DHP-/- mice. WT (closed circles, $n=5$ ) or $\mathrm{Ca}_{v} 1.2 \mathrm{DHP} \mathrm{P}^{-/-}$(open circles, $n=5$ ) mice were injected subcutaneously with $2 \mathrm{mg} / \mathrm{kg}$ BayK and placed singly in $20 \mathrm{~cm} \times 30 \mathrm{~cm}$ clear plastic cages. They were then observed for 1 minute each at 5-minute intervals. Motor disability was rated at each timepoint on a 4-point scale according to Jinnah et al. (8). No motor symptoms or abnormal behavior were observed after injection of vehicle alone. 

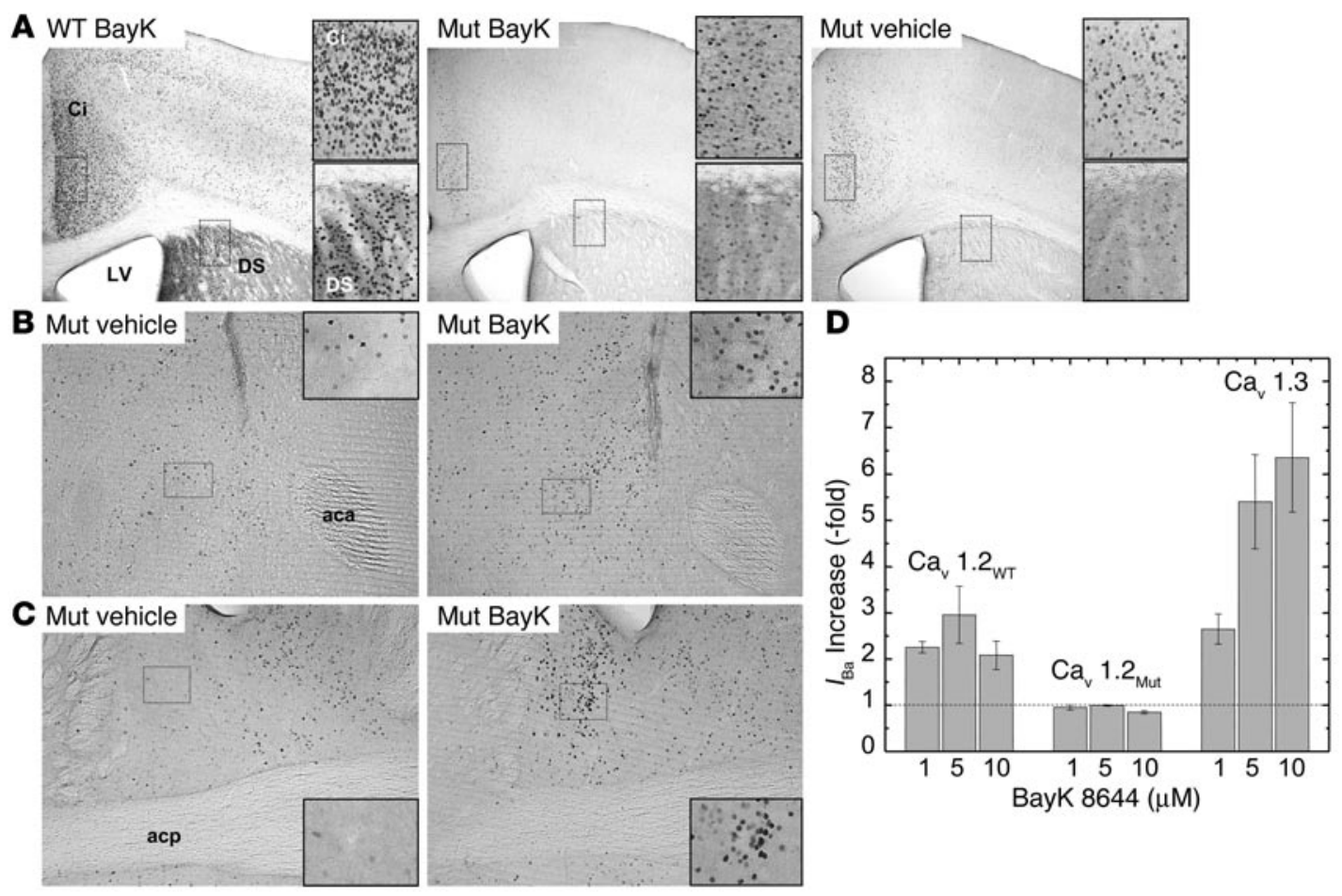

\section{Figure 6}

BayK-induced Fos expression in WT and $\mathrm{Ca}_{v} 1.2 \mathrm{DHP}-1-$ mice. Mice were injected with vehicle or BayK solution (WT, $\left.2 \mathrm{mg} / \mathrm{kg} ; \mathrm{mutants}, 4 \mathrm{mg} / \mathrm{kg}\right)$ and Fos expression was quantified by immunohistochemistry as described in Methods. (A) DS, dorsal striatum; Ci, cingulate cortex; LV, lateral ventricle. Magnification, $\times 40$. Inset shows higher magnification of boxed areas. (B) Fos expression after BayK (right) or vehicle (left) application in the nucleus accumbens. aca, anterior commissure, anterior. Magnification, $\times 100$. Inset magnification, $\times 800$. (C) Fos expression after BayK (right) or vehicle (left) application in the BNST. Magnification, $\times 100$. Inset magnification, $\times 800$ (boxed area in the lateral division). acp, anterior commissure, posterior. (D) Stimulation of $I_{\mathrm{Ba}}$ through $\mathrm{Ca}_{v} 1.2\left(\mathrm{Ca}_{\mathrm{v}} 1.2 \mathrm{wT}\right)$, mutant $\mathrm{Ca}_{\mathrm{v}} 1.2\left(\mathrm{Ca}_{\mathrm{v}} 1.2 \mathrm{MUT}_{\mathrm{T}}\right)$, and $\mathrm{Ca}_{\mathrm{v}} 1.3$ by BayK after heterologous expression under identical conditions in tsA-201 cells as described (15). Based on DHP pharmacokinetic data in mice (53), we calculated BayK concentration in brain to reach concentrations between $\sim 7 \mu \mathrm{M}$ (peak concentration) and $\sim 1 \mu \mathrm{M}$ (after three elimination half-lives). All data were significantly different from 1 (control before drug application) $(P<0.05$; one-sample Student's $t$ test) except Ca $1.2 \mathrm{MUT}, 1 \mu \mathrm{M}$ and $5 \mu \mathrm{M}$ BayK).

expressed and LTCC activators induce CREB phosphorylation and c-Fos expression in this area (see above) (36).

No difference in basal efflux of dopamine, noradrenaline, 5HT, or glutamate was found between WT mice and homozygous mutants ( $n=5-6$, see legend to Figure 7). In WT mice, superfusion with $0.1 \mu \mathrm{M}$ BayK increased the efflux of all studied neurotransmitters (Figure 7). BayK-induced neurotransmitter efflux was similar in WT and mutant mice for noradrenaline (fold increase: WT, $1.34 \pm 0.05, n=6 ; \mathrm{Ca}_{v} 1.2 \mathrm{DHP}^{-/-}, 1.39 \pm 0.12, n=5, P>0.6$ ), but was significantly attenuated in mutant mice for dopamine (fold increase: WT, $\left.2.94 \pm 0.35, n=6 ; C a_{v} 1.2 \mathrm{DHP}^{-/}, 1.53 \pm 0.10, n=5, P<0.01\right)$ and absent for glutamate (fold increase: WT, $14.35 \pm 7.26, n=6$; $\mathrm{Ca}_{v} 1.2 \mathrm{DHP} \mathrm{P}^{-/}$, $1.76 \pm 1.06, n=5$ ) and 5-HT efflux (fold increase: WT, $3.12 \pm 1.27$, $n=6 ; \mathrm{Ca}_{v} 1.2 \mathrm{DHP}^{-/-}, 1.05 \pm 0.07 ; n=4$; all by Mann-Whitney $U$ test) (Figure 7). Systemic application of BayK $(2 \mathrm{mg} / \mathrm{kg}$ given intraperitoneally) in mutants also significantly enhanced noradrenaline (fold increase: $1.68 \pm 0.21 ; n=5, P=0.03$ ) and dopamine efflux (fold increase: $1.30 \pm 0.08 ; n=5, P=0.04$ ) but not glutamate (fold increase: $0.79 \pm 0.26 ; n=4, P>0.7$ ) and 5-HT (fold increase: $0.98 \pm 0.35 ; n=3, P=1.00$ ) within $10-20$ minutes after drug application, suggesting that the stimulatory effect of BayK is not limited to intrastriatal application. We conclude that in the ventral striatum, BayK-induced noradrenaline efflux was mediated only through $\mathrm{Ca}_{\mathrm{v}} 1.3$, whereas enhanced glutamate and
5-HT efflux required $\mathrm{Ca}_{v}$ 1.2. Dopamine efflux stimulation was mediated by both isoforms.

$C a_{v} 1.3$ activation induces depression-like behavioral effects. Some of the regions activated by BayK in $\mathrm{Ca}_{v} 1.2 \mathrm{DHP}^{-/-}$mice, such as the PVN, BNST, ventral striatum, or amygdala, are part of anatomical circuits implicated in the processing of depression-related behavior (37). In addition, antidepressant-like effects of DHP LTCC blockers have been reported in rodents (see Introduction). The preferred test for demonstrating antidepressant-like effects in rodents is the Porsolt behavioral despair (forced-swim) test (38). In this test the extent of immobility (passive floating) displayed by rodents during a swim challenge is taken as a measure of depression-like behavior, which is decreased by antidepressants. We therefore also used this experimental paradigm to investigate the role of $\mathrm{Ca}_{v} 1.3$ for DHP effects on mood behavior.

Administration of BayK to $\mathrm{Ca}_{v} 1.2 \mathrm{DHP}^{-/-}$mice caused a pronounced increase of immobility time (Figure $8 \mathrm{C}$ ), indicating that BayK is able to induce a depression-like behavior in $\mathrm{Ca}_{v} 1.2 \mathrm{DHP} \mathrm{P}^{-/-}$ mice. The neurotoxic effects of BayK precluded parallel behavioral tests in WT mice. BayK did not affect motor function in the rotarod treadmill test (see above) or spontaneous motor activity in the openfield test (distance traveled in 10 minutes: vehicle, $1,727.6 \pm 87.7 \mathrm{~mm}$, $n=7$; BayK, 1,940.3 $\pm 117.9 \mathrm{~mm}, P=0.142$; center entries: vehicle, $13.3 \pm 1.8, n=7$; BayK, $13.9 \pm 3.0, n=7, P=1.00$ by Mann-Whit- 

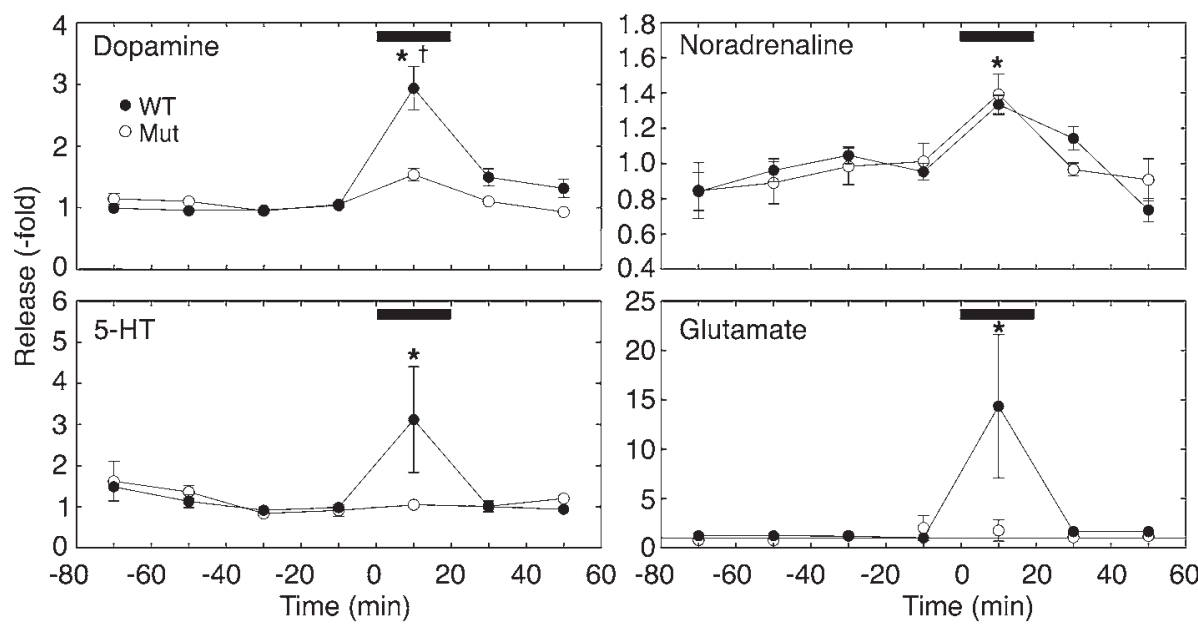

Figure 7

BayK-stimulated neurotransmitter efflux in the ventral striatum. Effect of intrastriatal administration of BayK $(0.1 \mu \mathrm{M})$ on neurotransmitter efflux in WT (filled circles) and $\mathrm{Ca}_{v} 1.2 \mathrm{DHP}^{-/-}$(open circles) mice. The bars indicate the application of $0.1 \mu \mathrm{M}$ BayK. Data were normalized to the mean efflux rates in the two samples (control efflux) preceding drug application. Baseline efflux ( $\mathrm{fmol} / \mathrm{min}$ ) in WT mice $(n=6)$ was: dopamine, $2.84 \pm 0.44$; noradrenaline, $0.77 \pm 0.08 ; 5-\mathrm{HT}, 1.10 \pm 0.21$; and glutamate, $974 \pm 193$. Baseline efflux ( $\mathrm{fmol} / \mathrm{min})$ in $\mathrm{Ca}_{v} 1.2 \mathrm{DHP} \mathrm{P}^{-/-}$mice $(n=5)$ was: dopamine, $2.02 \pm 0.27$; noradrenaline, $0.58 \pm 0.08 ; 5-\mathrm{HT}, 0.96 \pm 0.09$; glutamate, $1,107 \pm 161$. Statistically significant differences from control efflux were determined using the Friedman test followed by the Wilcoxon signed-rank test $\left({ }^{\star} P<0.05\right)$. Differences between WT and mutant mice were calculated using the Mann-Whitney $U$ test $\left({ }^{\dagger} P<0.05\right)$.

ney $U$ test). These findings emphasize the specificity of the BayK response in the forced-swim test, excluding the possibility that the decrease in activity of $\mathrm{Ca} a_{v} 1.2 \mathrm{DHP}^{-/}$mice in this test is due to generally impaired mobility or decreased motor performance. Figure 8A illustrates that in WT mice, $25 \mathrm{mg} / \mathrm{kg}$ of nifedipine reduced immobility time in accordance with previous studies $(5,39,40)$. In control experiments, desipramine $(10 \mathrm{mg} / \mathrm{kg})$ also decreased immobility time (not shown). The antidepressant action of nifedipine was absent in $\mathrm{Ca}_{v} 1.2 \mathrm{DHP} \mathrm{P}^{-/}$mice (Figure 8B), demonstrating that this effect is due to specific DHP block of $\mathrm{Ca}_{\mathrm{v}}$ 1.2. Although the nifedipine effects in WT mice need to be interpreted with caution due to its known cardiovascular effects (see above), the depressant-like effect of BayK in $\mathrm{Ca}_{v} 1.2 \mathrm{DHP} \mathrm{P}^{-/-}$mice provides convincing evidence that LTCC activation in the CNS can affect mood behavior.

\section{Discussion}

We report the successful generation of a novel mouse model that allows us to discriminate DHP effects on $\mathrm{Ca}_{v} 1.2$ from other LTCC isoforms. As verified in ventricular myocytes, in vivo mutation of Thr1066 to tyrosine (T1066Y) completely removed BayK modulation of $\mathrm{Ca}_{\mathrm{v}} 1.2$. It also dramatically reduced DHP blocker sensitivity, rendering isradipine highly selective for $\mathrm{Ca}_{v} 1.3$. This pharmacological phenotype was achieved without detectable alterations in channel gating or $\mathrm{Ca}_{\mathrm{v}} 1.2 \alpha 1$ expression. High-affinity DHP binding in brain was reduced to a level (20\%) known to be associated with $\mathrm{Ca}_{v} 1.3(1,30)$. Any remaining BayK effects in nonretinal neurons must therefore be $\mathrm{Ca}_{\mathrm{v}} 1.3$ mediated. This must also hold true for most other tissues in which the other known LTCC isoforms, $\mathrm{Ca}_{v} 1.4$ (restricted expression in retinal neurons; see refs. in ref. 41) and
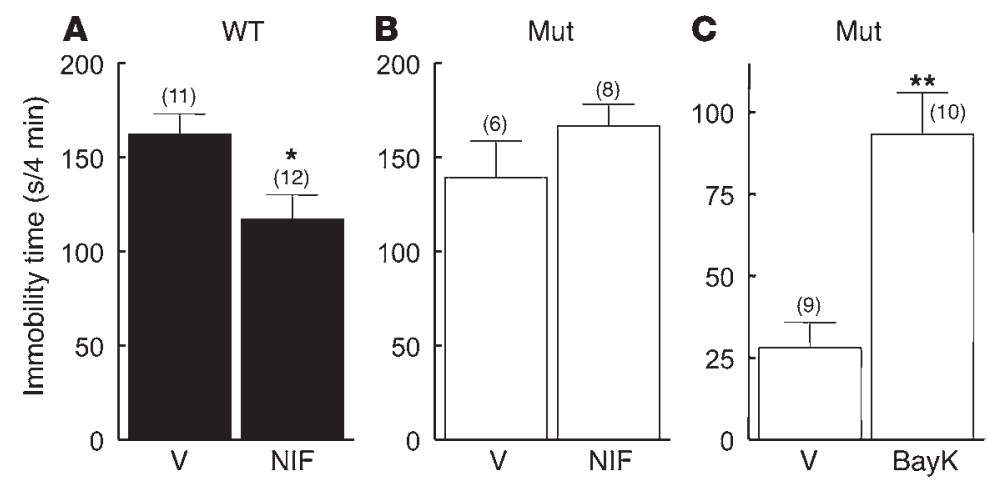

\section{Figure 8}

Effect of nifedipine and BayK on immobility time in the forced-swim test. Immobility times determined during the last 4 minutes of a 6-minute test period after intraperitoneal injection of vehicle or DHPs. Due to its neurotoxicity, BayK was not tested in WT mice. The number of experiments is indicated in parentheses. (A and B) Immobility times of WT and $\mathrm{Ca}_{v} 1.2 \mathrm{DHP}^{-/-}$mice 60 minutes after application of nifedipine (NIF, $25 \mathrm{mg} / \mathrm{kg}$ ) or vehicle (V). A pre-test was performed 24 hours before the test to increase immobility times. ${ }^{*} P<0.05$ by Mann-Whitney $U$ test. (C) Immobility times of $\mathrm{Ca}_{v} 1.2 \mathrm{DHP} \mathrm{P}^{-/-}$mice 20 minutes after application of BayK $\left(4 \mathrm{mg} / \mathrm{kg}\right.$ ) or vehicle $(\mathrm{V})$ without pre-test. ${ }^{* \star} P<0.01$ by Mann-Whitney $U$ test. 
would complicate analysis of CNS effects. These data also resolve the conundrum regarding the molecular identity of the LTCC in $\beta$ cells. Our data strongly suggest that in mouse $\beta$ cells, contrary to previous reports $(9,10), \mathrm{Ca}_{v} 1.2$ channels represent the most important conduit of $\mathrm{Ca}^{2+}$ entry involved in insulin secretion.

The bradycardiac effect of isradipine on intrinsic sinoatrial node activity observed in "pharmacologically denervated" hearts provides in vivo proof for our in vitro data demonstrating that $\mathrm{Ca}_{\mathrm{v}} 1.3$ is the major LTCC controlling diastolic depolarization in resting animals $(12,29)$. Interestingly, BayK did not cause a significant increase in heart rate, not even at the high doses used in $\mathrm{Ca}_{v} 1.2 \mathrm{DHP} \mathrm{P}^{-/-}$mice. This indicates that $\mathrm{Ca}_{v} 1.3$ channels stabilize normal heart rate (29) but that their selective pharmacological activation does not exert pronounced acceleration of intrinsic sinoatrial node automaticity in vivo.

We also show that DHP activator and blocker effects on the contractility of heart ventricular muscle and aortic smooth muscle are exclusively mediated by $\mathrm{Ca}_{v} 1.2$. The complete absence of BayK and isradipine effects on smooth muscle contraction is surprising because $\mathrm{Ca}_{\mathrm{v}} 1.3 \alpha 1$ subunits are expressed in aortic muscle (11). In mammals, vasodilation induced by DHP channel blockers and vasoconstriction induced by BayK $(13,43)$ may alter cerebral blood flow, thus complicating the interpretation of CNS effects in vivo. The absence of these effects in $\mathrm{Ca}_{v} 1.2 \mathrm{DHP}^{-/-}$mice provides us with a unique model to extend in vitro pharmacological research on neuronal LTCC function to the in vivo level.

CNS effects of $\mathrm{Ca}_{v} 1.3$-selective modulators. Another important prerequisite to analyze the consequences of selective $\mathrm{Ca}_{v} 1.3$ activation is the absence of neurotoxic effects. Although we found that $20 \%$ of the total LTCC activity in the CNS is associated with $\mathrm{Ca}_{v} 1.3$, all the neurotoxic symptoms observed after application of BayK in WT animals were completely absent even at very high doses (10 $\mathrm{mg} / \mathrm{kg}$ given intraperitoneally). Dystonia and neurobehavioral abnormalities, like self-biting (34), therefore require enhanced $\mathrm{Ca}^{2+}$ influx through $\mathrm{Ca}_{\mathrm{v}} 1.2$. This finding demonstrates a role of $\mathrm{Ca}_{\mathrm{v}} 1.2$ hyperactivity in dystonic symptoms. It is also supported by the previous observation that upregulation of $\mathrm{Ca}_{\mathrm{v}} 1.2$ expression in cerebellar Purkinje cells may be responsible for dystonic episodes in tottering mutant mice, which suffer from a complex neurological syndrome caused by mutations in a non-L-type $\mathrm{Ca}^{2+}$ channel $\left(\mathrm{Ca}_{v} 2.1\right)$ (44). Our study should therefore prompt further analysis of the role of LTCC dysfunction in dystonic syndromes.

The absence of neurotoxicity also allowed us to demonstrate that $\mathrm{Ca}_{\mathrm{v}} 1.3$-selective activation directly activates neuronal circuits. This could be shown both as a stimulation of neurotransmitter release as well as an increased Fos expression. Whereas BayK induced ubiquitous Fos expression in WT brains, the Fos response was greatly attenuated in $\mathrm{Ca}_{v} 1.2 \mathrm{DHP}^{-/-}$brains. This suggests that this drug effect is mainly transduced by $\mathrm{Ca}_{v} 1.2$. BayK-induced Fos expression in $\mathrm{Ca}_{v} 1.2 \mathrm{DHP}^{-/-}$mice was noted in only a few regions, including limbic and hypothalamic areas such as the BNST, nucleus accumbens, amygdala, and the PVN. The activation of this set of areas, implicated in functions such as the integration of emotionrelated behavior, drug addiction, learning, and memory, should prompt further studies with $\mathrm{Ca}_{v} 1.2 \mathrm{DHP} \mathrm{P}^{-/-}$mice to reveal the role of $\mathrm{Ca}_{\mathrm{v}} 1.3$ in DHP effects on these brain functions $(6,45-47)$.

Elimination of $\mathrm{Ca}_{v} 1.2$ BayK sensitivity not only prevented neuronal activation of certain brain regions but also resulted in differential effects on neurotransmitter release in the ventral striatum. In anesthetized WT mice, spontaneous efflux of all four studied neurotransmitters (dopamine, noradrenaline, 5-HT, and glutamate) was significantly enhanced by intrastriatal administration of BayK. Since no cell bodies of noradrenergic, dopaminergic, 5-HTergic, or glutamatergic neurons are present, these neurotransmitters are most likely released from projection neurons, originating for example from the ventral tegmental area (dopaminergic), cortical areas (glutamatergic), the dorsal raphe nucleus (5-HT-ergic), or locus coeruleus (noradrenergic). Therefore, locally applied BayK enhances neurotransmitter efflux either directly, by activation of presynaptic LTCCs $(48,49)$, or indirectly, by affecting striatal neuronal networks controlling neurotransmitter efflux from these afferents. In the ventral striatum, $\mathrm{Ca}_{v} 1.2$ and $\mathrm{Ca}_{v} 1.3$ contribute to a different extent to BayK-induced neurotransmitter efflux. Enhancement of extracellular glutamate and 5-HT was completely dependent on $\mathrm{Ca}_{v} 1.2$ channels. In contrast, the selective activation of $\mathrm{Ca}_{\mathrm{v}} 1.3$ was sufficient to stimulate extraneuronal dopamine and noradrenaline activity. Thus, a specific neurotransmitter efflux pattern can be induced by acutely activating $\mathrm{Ca}_{v} 1.3$. It remains to be shown whether this can also be observed in other brain areas.

In $\mathrm{Ca}_{v} 1.2 \mathrm{DHP}^{-/-}$mice, we can now show that this neuronal activation pattern resulting from selective $\mathrm{Ca}_{\mathrm{v}} 1.3$ activation also affects brain function in a specific manner. BayK increased depressionlike behavior without affecting locomotor activity, thus providing convincing evidence that $\mathrm{Ca}_{v} 1.3$ hyperactivity can alter mammalian mood-related behavior. We also confirmed that DHP channel blockers induce antidepressant-like effects, which we found to be $\mathrm{Ca}_{v} 1.2$ dependent. Based on our findings with BayK it seems likely that this is mainly due to modulation of neuronal LTCC activity rather than indirect cardiovascular effects.

It is assumed that many brain areas mediate the diverse symptoms of depression (50). Interestingly, BayK particularly increased Fos expression in subcortical brain areas thought to be abnormal in depression, including the nucleus accumbens, amygdala, and the PVN (50). Similarly, the BNST, which displayed enhanced BayK-induced Fos expression, has also been implicated in depression-like behavior (51). As only a limited number of regions are activated by BayK in $\mathrm{Ca}_{v} 1.2 \mathrm{DHP}^{-/-}$brains, this animal model represents a useful and novel tool to further study neuronal circuits underlying depression-like behavior (37). Moreover, if the depression-like behavior induced by BayK is reversed by known antidepressant drugs, then $C a_{v} 1.2 D H P^{-/-}$mice could serve as a novel animal model for depression suitable for the in vivo screening of antidepressant drug actions.

Our finding of an acute depressant-like effect of BayK establishes a role for LTCC in mood behavior but does not suggest therapeutic benefit. However, final predictions about the pharmacotherapeutic potential of selective $\mathrm{Ca}_{\mathrm{v}} 1.3$ activators must await experimental results from chronic treatment (weeks to months) with different doses of DHP channel activators. The differential effects on neurotransmitter release observed in $\mathrm{Ca}_{v} 1.2 \mathrm{DH} \mathrm{P}^{-/-}$brains could lead to adaptive neuronal phenomena resulting in CNS effects not observed upon acute administration. This is for example observed for selective serotonin reuptake inhibitors (SSRIs), where only chronic administration results in therapeutic antidepressant effects, whereas anxiogenic side effects are present at the beginning of therapy in animals and humans (see refs. in ref. 52). Our new mouse model paves the way for the elucidation of the contribution of $\mathrm{Ca}_{v} 1.3$ to diverse physiological functions. It will be especially suitable to predict pharmacological effects of selective $\mathrm{Ca}_{v} 1.3$ activation on CNS function. 


\section{Acknowledgments}

We thank G. Pelster, J. Aldrian, E. Margreiter, and P. Bauer for excellent technical assistance and M. Brennsteiner for animal care. This work was supported by grants from the Austrian Science Fund (P-14820 to J. Striessnig and T38 to M. Sinnegger-Brauns), the European Community (IHRP-CT-2000-00082), the University of Innsbruck, the Austrian National Bank, and the Swedish Research Council $(8647,12234$, and 13509).

1. Hell, J.W., et al. 1993. Identification and differential subcellular localization of the neuronal class C and class D L-type calcium channel $\alpha 1$ subunits. J. Cell. Biol. 123:949-962.

2. Zakharenko, S.S., Zablow, L., and Siegelbaum, S.A. 2001. Visualization of changes in presynaptic function during long-term synaptic plasticity. Nat. Neurosci. 4:711-717.

3. Deisseroth, K., Mermelstein, P.G., Xia, H., and Tsien, R.W. 2003. Signaling from synapse to nucleus: the logic behind the mechanisms. Curr. Opin. Neurobiol. 13:354-365.

4. Veng, L.M., Mesches, M.H., and Browning, M.D. 2003. Age-related working memory impairment is correlated with increases in the L-type calcium channel protein $\alpha_{1} \mathrm{D}$ (Cav1.3) in area CA1 of the hippocampus and both are ameliorated by chronic nimodipine treatment. Brain Res. Mol. Brain Res. 110:193-202.

5. Mogilnicka, E., Czyrak, A., and Maj, J. 1988. BAY K 8644 enhances immobility in the mouse behavioral despair test, an effect blocked by nifedipine. Eur. J. Pharmacol. 151:307-311.

6. Bauer, E.P., Schafe, G.E., and LeDoux, J.E. 2002. NMDA receptors and L-type voltage-gated calcium channels contribute to long-term potentiation and different components of fear memory formation in the lateral amygdala. J. Neurosci. 22:5239-5249.

7. Miller, R.J. 1987. Multiple calcium channels and neuronal function. Science. 235:46-52.

8. Jinnah, H.A., et al. 2000. Calcium channel agonists and dystonia in the mouse. Mov. Disord. 15:542-551.

9. Yang, S.N., et al. 1999. Syntaxin 1 interacts with the L(D) subtype of voltage-gated $\mathrm{Ca}^{2+}$ channels in pancreatic $\beta$ cells. Proc. Natl. Acad. Sci. U. S. A. 96:10164-10169.

10. Namkung, Y., et al. 2001. Requirement for the L-type $\mathrm{Ca}^{2+}$ channel $\alpha_{1 \mathrm{D}}$ subunit in postnatal pancreatic $\beta$ cell generation. J. Clin. Invest. 108:1015-1022. doi:10.1172/JCI200113310.

11. Takimoto, K., Li, D., Nerbonne, J.M., and Levitan, E.S. 1997. Distribution, splicing and glucocorticoidinduced expression of cardiac $\alpha_{1} \mathrm{C}$ and $\alpha_{1} \mathrm{D}$ voltage-gated $\mathrm{Ca}^{2+}$ channel mRNAs. J. Mol. Cell. Cardiol. 29:3035-3042.

12. Mangoni, M.E., et al. 2003. Functional role of L-type Cav1.3 $\mathrm{Ca}^{2+}$ channels in cardiac pacemaker activity. Proc. Natl. Acad. Sci. U. S. A. 100:5543-5548.

13. Petty, M.A., and Mir, A.K. 1988. Comparison of the cardiovascular effects of trans-diclofurime with different types of calcium antagonists in conscious spontaneously hypertensive rats. Br. J. Pharmacol. 94:1218-1224.

14. Wappl, E., Mitterdorfer, J., Glossmann, H., and Striessnig, J. 2001. Mechanism of dihydropyridine interaction with critical binding residues of L-type $\mathrm{Ca}^{2+}$ channel $\alpha_{1}$ subunits. J. Biol. Chem. 276:12730-12735.

15. Koschak, A., et al. 2001. $\alpha_{1}$ D (Cav1.3) subunits can form L-type $\mathrm{Ca}^{2+}$ channels activating at negative voltages. J. Biol. Chem. 276:22100-22106.

16. Huber, I., et al. 2000. Conserved $\mathrm{Ca}^{2+}$ antagonist binding properties and putative folding structure of a recombinant high affinity dihydropyridine binding domain. Biochem. J. 347:829-836.

17. Liu, L., Gonzalez, P.K., Barrett, C.F., and Rittenhouse, A.R. 2003. The calcium channel ligand FPL 64176
Received for publication October 3, 2003, and accepted in revised form February 17, 2004.

Address correspondence to: Jörg Striessnig, Abteilung Pharmakologie und Toxikologie, Institut für Pharmazie, Universität Innsbruck, Peter Mayr-Strasse 1/I, A-6020 Innsbruck, Austria. Phone: 43-512-507-5600; Fax: 43-512-507-2931; E-mail: joerg. striessnig@uibk.ac.at. enhances L-type but inhibits N-type neuronal calcium currents. Neuropharmacology. 45:281-292.

18. Singewald, N., and Sharp, T. 2000. Neuroanatomical targets of anxiogenic drugs in the hindbrain as revealed by Fos immunocytochemistry. Neuroscience. 98:759-770.

19. Franklin, K.B.J., and Paxinos, G. 1997. The mouse brain in stereotaxic coordinates. 1st edition. Academic Press. London, United Kingdom.

20. Singewald, N., Kaehler, S., Hemeida, R., and Philippu, A. 1997. Release of serotonin in the rat locus coeruleus: effects of cardiovascular, stressful and noxious stimuli. Eur. J. Neurosci. 9:556-562.

21. Singewald, N., and Philippu, A. 1993. Catecholamine release in the locus coeruleus is modified by experimentally induced changes in haemodynamics. Naunyn Schmiedebergs Arch. Pharmacol. 347:21-27.

22. Singewald, N., Schneider, C., and Philippu, A. 1994. Effects of neuroactive compounds, noxious and cardiovascular stimuli on the release of amino acids in the rat locus coeruleus. Neurosci. Lett. 180:55-58.

23. Thiele, T.E., Koh, M.T., and Pedrazzini, T. 2002. Voluntary alcohol consumption is controlled via the neuropeptide YY1 receptor. J. Neurosci. 22:RC208.

24. Tschenett, A., et al. 2003. Reduced anxiety and improved stress coping ability in mice lacking NPYY2 receptors. Eur. J. Neurosci. 18:143-148.

25. Eller, P., et al. 2000. High affinity interaction of mibefradil with voltage-gated calcium and sodium channels. Br. J. Pharmacol. 130:669-677.

26. Schulla, V., et al. 2003. Impaired insulin secretion and glucose tolerance in $\beta$ cell-selective Ca $1.2 \mathrm{Ca}^{2+}$ channel null mice. EMBO J. 22:3844-3854.

27. Bova, S., et al. 1996. Vasorelaxant properties of norbormide, a selective vasoconstrictor agent for the rat microvasculature. Br. J. Pharmacol. 117:1041-1046.

28. Bova, S., et al. 1997. Calcium-antagonist effects of norbormide on isolated perfused heart and cardiac myocytes of guinea-pig: a comparison with verapamil. Br. J. Pharmacol. 120:19-24.

29. Platzer, J., et al. 2000. Congenital deafness and sinoatrial node dysfunction in mice lacking class D L-type $\mathrm{Ca}^{2+}$ channels. Cell. 102:89-97.

30. Clark, N.C., et al. 2003. Neurological phenotype and synaptic function in mice lacking the $\mathrm{Ca}_{\mathrm{v}} 1.3$ alpha subunit of neuronal L-type voltage-dependent $\mathrm{Ca}^{2+}$ channels. Neuroscience. 120:435-442.

31. Koschak, A., et al. 2003. Cav1.4 $\alpha_{1}$ subunits can form slowly inactivating dihydropyridine-sensitive L-type $\mathrm{Ca}^{2+}$ channels lacking $\mathrm{Ca}^{2+}$-dependent inactivation. J. Neurosci. 23:6041-6049.

32. Barg, S., et al. 2001. Fast exocytosis with few $\mathrm{Ca}^{2+}$ channels in insulin-secreting mouse pancreatic B cells. Biophys. J. 81:3308-3323.

33. Larsson-Nyren, G., Sehlin, J., Rorsman, P., and Renstrom, E. 2001. Perchlorate stimulates insulin secretion by shifting the gating of L-type $\mathrm{Ca}^{2+}$ currents in mouse pancreatic B-cells towards negative potentials. Pflugers Arch. 441:587-595.

34. Jinnah, H.A., et al. 1999. Calcium channel activation and self-biting in mice. Proc. Natl. Acad. Sci. U. S. A. 96:15228-15232.

35. Olive, M.F., Mehmert, K.K., Messing, R.O., and Hodge, C.W. 2000. Reduced operant ethanol selfadministration and in vivo mesolimbic dopamine responses to ethanol in PKCepsilon-deficient mice. Eur. J. Neurosci. 12:4131-4140.
36. Rajadhyaksha, A., et al. 1999. L-Type $\mathrm{Ca}^{2+}$ channels are essential for glutamate-mediated CREB phosphorylation and $\mathrm{c}$-fos gene expression in striatal neurons. J. Neurosci. 19:6348-6359.

37. Manji, H.K., Drevets, W.C., and Charney, D.S. 2001. The cellular neurobiology of depression. Nat. Med. 7:541-547.

38. Porsolt, R.D., Le Pichon, M., and Jalfre, M. 1977. Depression: a new animal model sensitive to antidepressant treatments. Nature. 266:730-732.

39. Cohen, C., Perrault, G., and Sanger, D.J. 1997. Assessment of the antidepressant-like effects of L-type voltage-dependent channel modulators. Behav. Pharmacol. 8:629-638.

40. Srivastava, S.K., and Nath, C. 2000. The differential effects of calcium channel blockers in the behavioural despair test in mice. Pharmacol. Res. 42:293-297.

41. Strom, T.M., et al. 1998. An L-type calcium-channel gene mutated in incomplete $\mathrm{X}$-linked congenital stationary night blindness. Nat. Genet. 19:260-263.

42. Ellis, S.B., et al. 1988. Sequence and expression of mRNAs encoding the $\alpha_{1}$ and $\alpha_{2}$ subunits of a DHPsensitive calcium channel. Science. 241:1661-1664.

43. Bourson, A., Moser, P.C., Gower, A.J., and Mir A.K. 1989. Central and peripheral effects of the dihydropyridine calcium channel activator BAY K 8644 in the rat. Eur. J. Pharmacol. 160:339-347.

44. Campbell, D.B., North, J.B., and Hess, E.J. 1999. Tottering mouse motor dysfunction is abolished on the Purkinje cell degeneration (pcd) mutant background. Exp. Neurol. 160:268-278.

45. Cain, C.K., Blouin, A.M., and Barad, M. 2002. L-type voltage-gated calcium channels are required for extinction, but not for acquisition or expression, of conditional fear in mice. J. Neurosci. 22:9113-9121.

46. Kuzmin, A., Zvartau, E., Gessa, G.L., Martellotta, M.C., and Fratta, W. 1992. Calcium antagonists isradipine and nimodipine suppress cocaine and morphine intravenous self-administration in drugnaive mice. Pharmacol. Biochem. Behav. 41:497-500.

47. Rossetti, Z.L., Isola, D., De Vry, J., and Fadda, F. 1999. Effects of nimodipine on extracellular dopamine levels in the rat nucleus accumbens in ethanol withdrawal. Neuropharmacology. 38:1361-1369.

48. Bonci, A., Grillner, P., Mercuri, N.B., and Bernardi, G. 1998. L-Type calcium channels mediate a slow excitatory synaptic transmission in rat midbrain dopaminergic neurons. J. Neurosci. 18:6693-6703.

49. Jensen, K., and Mody, I. 2001. L-type $\mathrm{Ca}^{2+}$ channelmediated short-term plasticity of GABAergic synapses. Nat. Neurosci. 4:975-976.

50. Nestler, E.J., et al. 2002. Neurobiology of depression. Neuron. 34:13-25.

51. Stout, S.C., Mortas, P., Owens, M.J., Nemeroff, C.B., and Moreau, J. 2000. Increased corticotropin-releasing factor concentrations in the bed nucleus of the stria terminalis of anhedonic rats. Eur. J. Pharmacol. 401:39-46.

52. Salchner, P., and Singewald, N. 2002. Neuroanatomical substrates involved in the anxiogenic-like effect of acute fluoxetine treatment. Neuropharmacology. 43:1238-1248.

53. Uchida, S., Yamada, S., Nagai, K., Deguchi, Y., and Kimura, R. 1997. Brain pharmacokinetics and in vivo receptor binding of 1,4-dihydropyridine calcium channel antagonists. Life Sci. 61:2083-2090. 